\title{
BANTUAN AWAL KESULITAN BELAJAR MATEMATIKA ANAK USIA DINI MELALUI INTERVENSI POLA DAN STRUKTUR
}

\author{
Timbul Yuwono, Tatik Retno Murniasih \\ Dosen Pendidikan Matematika Universitas Kanjuruhan Malang \\ timbulyuwono@gmail.com, tretnom@unikama.ac.id
}

\begin{abstract}
Abstrak
Penelitian ini bertujuan untuk mengetahui perolehan kesadaran pola dan struktur matematika pada anak usia dini. Subyek penelitian adalah siswa kelas B TK Permata Iman 2 Malang yang terdiri dari 21 siswa laki-laki dan perempuan berusia 5 - 6 tahun. Jenis penelitian adalah penelitian kualitatif, menggunakan strategi studi kasus. Studi kasus diarahkan pada intervensi pola dan struktur anak usia dini selama proses pembelajaran di sekolah. Hasil penelitian menunjukkan bahwa respon siswa untuk berbagai tugas bisa andal dikategorikan sesuai dengan fitur struktur matematika. Empat kategori perkembangan struktural meliputi: tahap pra-struktural, tahap emergent, tahap struktural parsial, dan tahap perkembangan struktural. Berdasarkan hasil penelitian dapat disimpulkan: a) siswa dapat menggunakan representasi numerik dalam bentuk gambar berpola, dan b) hasil pekerjaan siswa terdistribusi pada 5 anak kategori tahap pre-structural, 4 anak kategori tahap emergent, 5 anak kategori tahap partial, dan 7 anak kategori tahap structural.
\end{abstract}

Kata-kata Kunci: intervensi, pola dan struktur, representasi numerik

Abstract

This study aims to determine the acquisition of awareness of the mathematics pattern and structure in early childhood. Subjects were students of class B TK Permata Iman 2 Malang consisted of 21 male and female students of 5-6 years old. This study was a qualitative study, using a case study strategy. The case study is directed at intervention pattern and structure of early childhood during the learning process in schools. The results showed that the students' responses to various tasks can be reliably categorized according to the features of mathematical structures. Four categories of structural developments include: pre-structural, emergent stage, the stage of partial structural, structural and developmental stage. Based on the results of study we conclude that: a) students can use the numerical representation in the form of an image patterned, and b) based from the students' work, there are 5 children in category of pre-structural stage, 4 children in category of emergent stage, 5 children in category of partial stage, and 7 children in category of structural stage.

Key words: intervention, patterns and structures, a numerical representation

\section{PENDAHULUAN}

Tujuan utama dari program

Prasekolah adalah untuk mempersiapkan anak-anak usia dini agar berhasil belajar di jenjang Sekolah Dasar. Berdasarkan hasil penelitian program berkualitas tinggi memfasilitasi pembelajaran anak-anak dalam matematika (Clements \& Sarama, 2004). Salah satu program berkualitas tinggi yaitu melakukan intervensi awal dalam matematika. Intervensi dilakukan pada program
Prasekolah dengan cara memadukan praktek matematika sesuai dengan perkembangan anak sehingga kesulitan belajar pada saat sekolah formal dapat diatasi. Guru dapat mengetahui pemahaman awal tentang matematika, dengan cara observasi (mengamati perkembangan motorik dan kognitif melalui representasi anak) dan intervensi.

Strategi intervensi dini bertujuan untuk mencegah anak usia dini dari kesulitan 
belajar matematika, meremediasi dan untuk mendorong para pendidik anak guna memberikan kesempatan perkembangan pengayaan matematika anak sebelum sekolah formal (Doig, B, dkk, 2003). Tanpa intervensi aktif anak-anak dengan pengetahuan matematika sedikit di awal sekolah formal akan tetap berprestasi rendah di Sekolah Dasar (Aubrey, C, 2006). Hasil intervensi singkat menunjukkan pada pola berulang dapat bertindak sebagai jembatan yang efektif untuk memperkenalkan konsep perbandingan. Mereka juga menunjukkan bahwa representasi tertentu dan tindakan guru membatu siswa untuk mengidentifikasi perbandingan, memperoleh kesetaraan antara perbandingan tertentu, dan mulai untuk mewakili ide-ide ini dalam sistem notasi abstrak (Warren, E., \& Cooper, T. J. 2007).

Program matematika terbaru pada anak usia 4 sampai 8 tahun menekankan aspek pola dan hubungan struktural, termasuk kesetaraan, pola tumbuh, dan pemikiran fungsional (Warren \& Cooper, 2008). Kesadaran struktur matematika sangat penting pada anak usia dini (Mulligan, J. T., \& Mitchelmore, M. C. 2009).

Kesadaran siswa terhadap pola dan struktur sudah dapat menggunakan strategi spasial dan representasi spasial yang dianggap mendasar dalam pengolahan numerik (Butterworth, B., \& Reeve, R., 2008).

Guru pada anak usia dini di Sydney dan Brisbane Australia mengukur kesadaran anak tentang pola dan struktur bersifat matematika AMPS (Awareness of Mathematical Pattern and Structure), dengan intervensi PASMAP( Pattern and Structure Mathematics Awareness Program) Pattern and Structure Mathematical
Awareness. Hubungan antara pola dan kesadaran struktural pada pemahaman matematika awal memungkinkan untuk pengembangan pola yang lebih luas. Program kesadaran struktur matematika difokuskan pada kelanjutan belajar siswa pada tahun-tahun awal pendidikan formal (Mulligan. J. dkk, 2010)

Menurut (Papic, dkk, 2011), pengembangan strategi pola sebelum sekolah formal dipelajari oleh 53 anak dari 2 TK yang sama. Satu Prasekolah menerapkan 6 bulan intervensi berfokus pada pola berulang dan spasial. Anak-anak dari kelompok intervensi menunjukkan pemahaman yang lebih baik unit berulang dan penataan ruang, dan sebagian besar juga mampu memperluas dan menjelaskan pola tumbuh 1 tahun kemudian. Penelitian belum bisa menggambarkan secara eksplisit bagaimana pola dapat mengarah pada pengembangan konsepkonsep matematika dan penalaran pra-aljabar pada anak-anak.

Penelitian Mulligan, J. T. (2011), peserta diambil dari sembilan negara, dipilih dari enam distrik administratif metropolitan Sydney. Sampel 103 siswa kelas pertama (55 perempuan dan 48 laki-laki), mulai 4-9 tahun. Menunjukkan bahwa kesadaran pola matematis dan struktur sangat penting untuk pengembangan konsep-konsep matematika, keterampilan dan keahlian.

Berdasarkan latar belakang di atas peneliti tertarik melakukan intervensi pada anak-anak dalam bentuk penjelasan di papan tulis tentang struktur dan pola di TK Permata Iman 2. Sebagian anak sudah ada kesadaran struktur dan pola. Kesadaran struktur dan pola yang sudah dimiliki pada anak-anak dapat dijadikan dasar untuk pengembangan konsep-konsep matematika. 
Dengan demikian yang menjadi perhatian dalam penelitian ini adalah Apakah kesadaran pola dan struktur pada anak pra sekolah menjadi akar penyebab kesulitan belajar matematika? Penelitian ini diharapkan dapat dijadikan salah salah variabel dalam menyusun buku matematika anak usia dini.

\section{METODE PENELITIAN}

Jenis penelitian ini adalah penelitian kualitatif, menggunakan strategi studi kasus. Creswell (2012), mengatakan bahwa "studi kasus merupakan strategi penelitian dimana di dalamnya peneliti menyelidiki secara cermat suatu program, peristiwa, aktivitas, proses, atau sekelompok individu". Dalam penelitian ini peneliti menyelediki perolehan kesadaran struktur dan pola pada anak usia dini dimana peneliti mengumpulkan data secara lengkap dengan menggunakan berbagai prosedur pengumpulan data berdasarkan waktu yang telah ditentukan (Stake, dalam Creswell 2012).

Penelitian dilaksanakan di TK Permata Iman 2 Malang. Siswa diminta untuk menyelesaikan tugas berupa gambar, pola dan struktur pola. Berdasarkan hasil pekerjaan siswa peneliti mengelompokan hasil gambar siswa dan mengelompokan level strukturalnya.

Instrumen utama penelitian ini adalah peneliti yang dipandu dengan instrumen lembar gambar pola yang harus dikerjakan oleh siswa untuk mengetahui perolehan tahap pola dan struktur matematika yang diperoleh. Peneliti bertindak sebagai instrumen utama. Penelitian yang mengumpulkan data, menganalisis data, menafsirkan data, dan melaporkan hasil penelitian.

Lembar tugas pola terdiri dari 4 gambar pola berulang, pola membesar, pola tumbuh, gambar pola dan struktur untuk diteruskan siswa. Tugas menggambar tersebut untuk mengetahui tahap perkembangan pola dan struktur matematika anak. Instrumen tersebut dapat dilihat pada Gambar 1.

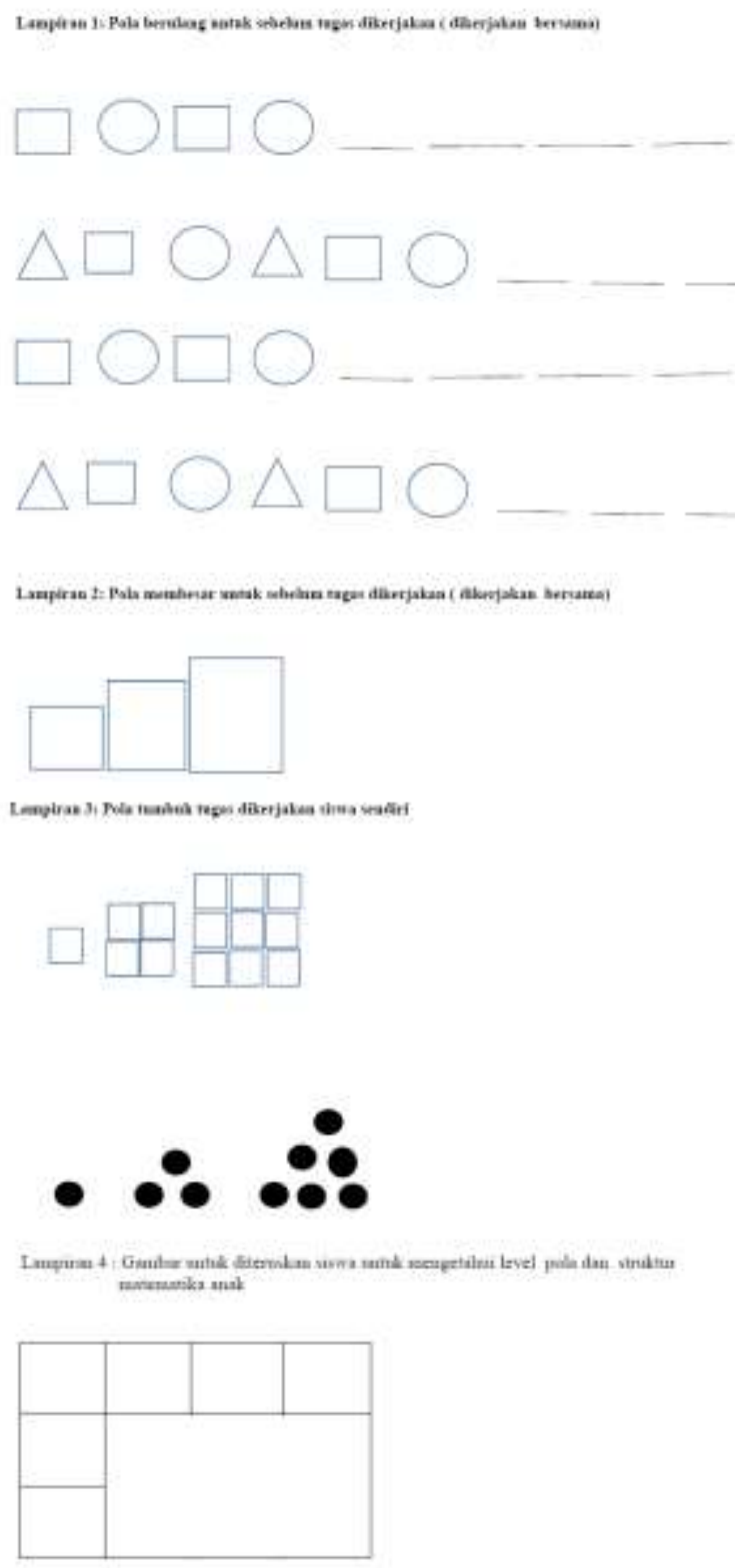

Gambar 1. Instrumen Penelitian 


\section{HASIL DAN PEMBAHASAN}

Observasi dilakukan di kelas B TK Permata Iman 2 yang terdiri dari 11 siswa laki-laki dan 10 siswa perempuan dengan umur siswa 11 siswa berumur 5 tahun dan 10 siswa berumur 6 tahun.

Hasil penelitian menunjukkan bahwa respon siswa untuk berbagai tugas bisa andal dikategorikan sesuai dengan fitur struktur matematika. Empat kategori perkembangan struktural menurut (Mulligan \& Mitchelmore, 2009), dapat dilihat pada Gambar 2 berikut ini:
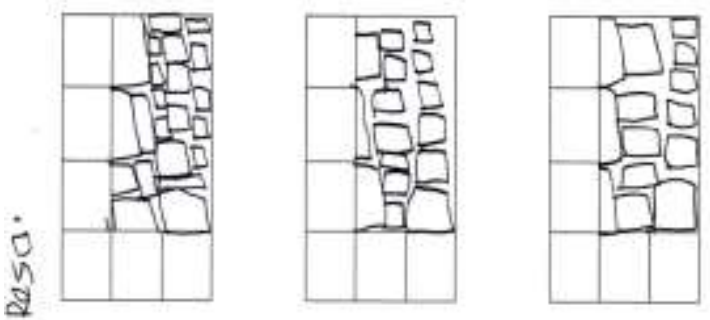

Gambar 2. Tahap Perkembangan Struktural

1. Tahap pre-structural (PRS). Representasi kekurangan adanya bukti numerik atau tata ruang.

2. Tahap Emergent (ES). Representasi menunjukkan beberapa elemen yang relevan dari struktur yang diberikan, tapi struktur numerik tidak terwakili.

3. Tahap Partial (PS). Representasi menunjukkan aspek yang paling relevan struktur numerik atau spasial, tetapi representasi tidak lengkap.

4. Tahap Structural (S). Representasi benar mengintegrasikan unsur struktur numerik dan spasial, (Mulligan, J.T., 2011).

Guru dan observer memulai intervensi dengan memberikan instruksi pada siswa Taman Kanak-kanak. Guru dan observer meminta siswa untuk menggambar kotak-kotak pada daerah yang belum terisi kotak. Kotak yang digambar mencontoh kotak-kotak disekitarnya. Hasil Pekerjaan siswa terdistribusi 5 anak pada tahap prastruktural, 4 anak pada tahap emergent, 5 anak pada tahap struktural parsial, dan 7 anak pada tahap struktural. Pada tahap prestructural diberikan salah satu contoh pekerjaan siswa seperti pada Gambar 3. Siswa tidak menunjukkan kesadaran pada struktur geometris persegi panjang atau kotak, ukuran kotak atau konsep daerah tertutup oleh batas.

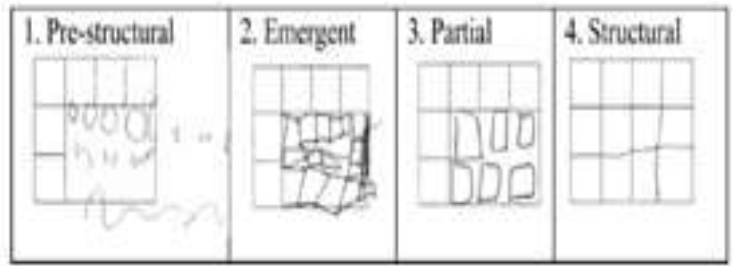

Gambar 3. Contoh Pekerjaan Siswa G Tahap PreStructural

Pekerjaan siswa tahap emergent, menunjukkan representasi beberapa (elemen) kotak yang relevan dengan struktur yang diberikan berupa kotak-kotak, tapi struktur numerik tidak terwakili karena berbeda jumlah (Gambar 4).

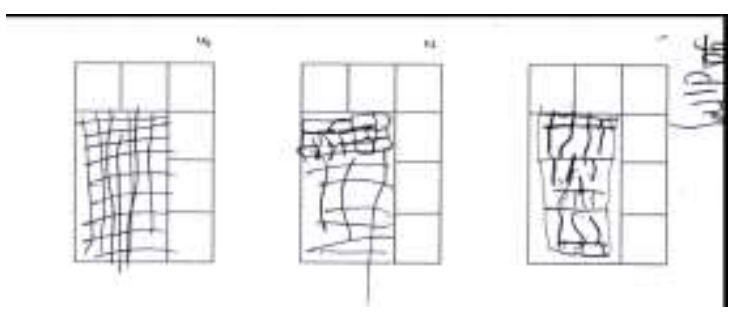

Gambar 4. Contoh Pekerjaan Siswa R Tahap Emergent

Pekerjaan siswa tahap partial menunjukkan representasi aspek yang paling relevan struktur numerik atau spasial, tetapi tidak representasi seperti Gambar 5. 


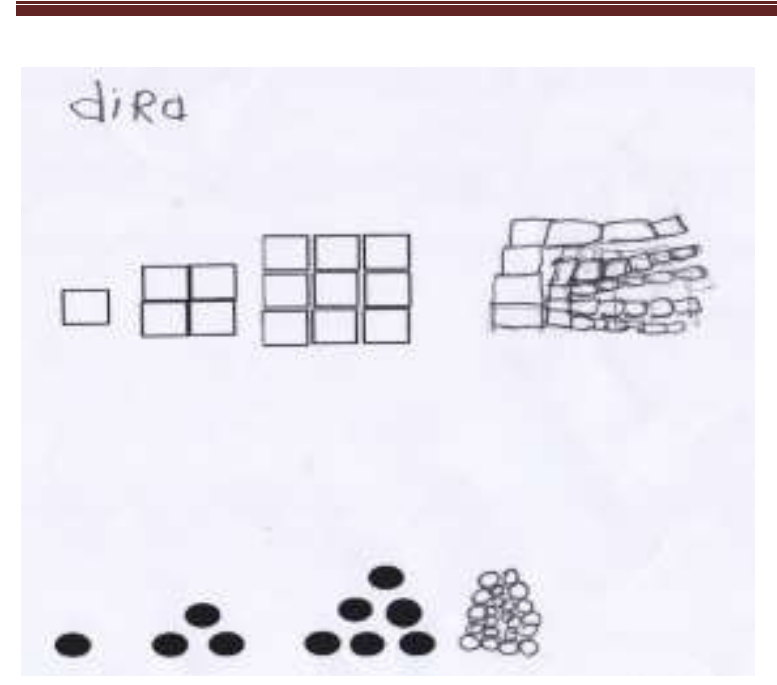

Gambar 5. Contoh Pekerjaan Siswa N Tahap Partial

Pekerjaan siswa tahap structural (S) menunjukkan representasi integrasi unsur struktur numerik dan spasial dengan benar (Gambar 6).
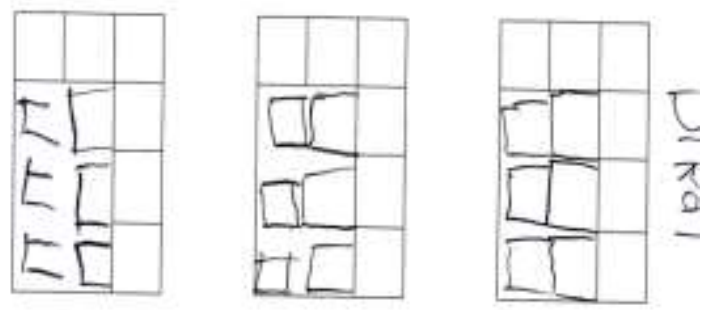

Gambar 6. Contoh Pekerjaan Siswa C Tahap Structural

Berdasarkan hasil pengamatan pada saat intervensi guru dan observer meminta siswa-siswa untuk memperhatikan penjelasan cara menggambar kotak-kotak pada lembar kertas yang sudah disediakan. Guru dan observer meminta siswa-siswa untuk meneruskan menggambar kotak-kotak di sebelah kanan gambar kotak-kotak yang sudah ada. Guru dan observer juga meminta anak-anak untuk menggambar lingkaran kecil-kecil disamping kanan gambar yang sudah ada dengan aturan yang sudah dijelaskan. Siswa menggambar pola pada lembar kertas yang disediakan hasilnya sebagai berikut:
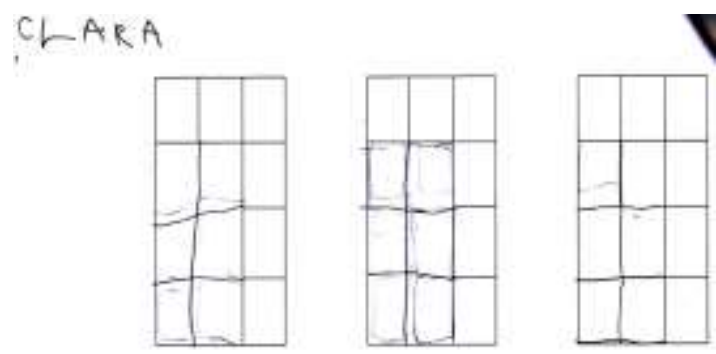

Gambar 7. Pola Tumbuh Kotak dan Titik Siswa G

Siswa bernama $\mathrm{G}$ pada Gambar 7 menggambar pola tumbuh kotak yaitu representasi elemen kotak sudah ada dan struktur numerik belum sempurna dapat dilihat pola tumbuh ke atas sudah benar, sedangkan pola tumbuh menyamping belum benar ini berarti representasi numerik belum terwakili. Siswa bernama G pada tahapan pre-structural yang masih belum menggunakan batas pada saat menggambar kotak di samping gambar yang sudah disediakan. Siswa menggambar pola tumbuh berdasarkan hasil gambar tersebut bahwa siswa sudah masuk tahap emergent. Pada kedua gambar pola tumbuh kotak dan lingkaran menunjukkan beberapa elemen kotak yang relevan dengan struktur yang diberikan berupa kotak-kotak dan lingkaran (titik-titik). 


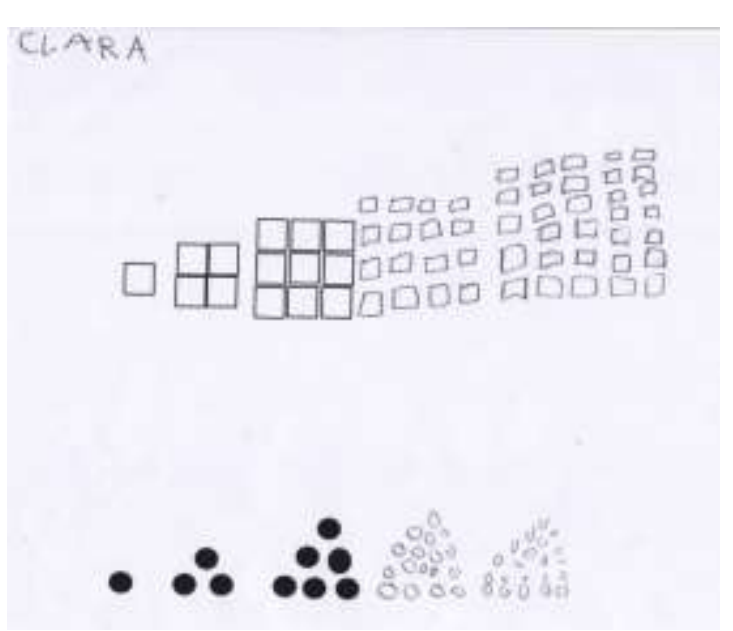

Gambar 8. Pola Tumbuh Kotak dan Titik Siswa D

Siswa bernama D pada Gambar 8 menggambar pola tumbuh kotak yaitu representasi elemen kotak sudah ada dan struktur numerik belum sempurna dapat dilihat pola tumbuh ke atas sudah benar, sedangkan pola tumbuh menyamping belum benar ini berarti representasi numerik belum terwakili. Pada Gambar 8 siswa bernama D tidak pada tahapan pre-structural. Siswa menggambar pola tumbuh berdasarkan hasil gambar tersebut bahwa siswa sudah masuk tahap emergent. Pada kedua gambar pola tumbuh kotak dan lingkaran menunjukkan beberapa elemen kotak yang relevan dengan struktur yang diberikan berupa kotak-kotak dan lingkaran. Pada kedua gambar pola tumbuh kotak dan lingkaran menunjukkan juga masih pada tahap parsial beberapa elemen kotak masih belum menjadi satu seperti gambar yang yang sudah diberikan.

\section{sading}

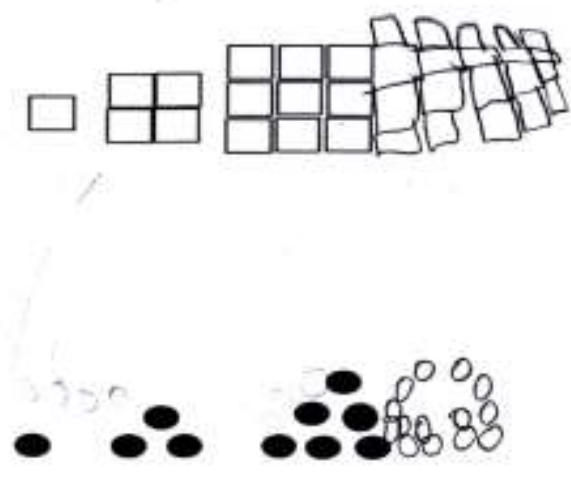

Gambar 9. Pola Tumbuh Kotak dan Titik Siswa C Siswa bernama C pada Gambar 9, menggambar pola tumbuh kotak representasi elemen sudah pada tahap perkembangan structural

Representasi mengintegrasikan unsur struktur numerik dan spasial dengan benar. Hal ini dapat dilihat pola tumbuh ke atas dan menyamping sudah benar. Ukuran kotak sudah sesuai, tetapi pada gambar titik-titik struktur numerik dan spasial belum benar masih belum menjadi satu seperti gambar yang yang sudah diberikan.

\section{PENUTUP}

Siswa dapat menggunakan reprentasi numerik dalam bentuk gambar berpola. Siswa cenderung menggambar pola tumbuh sudah ada dan struktur numerik belum sempurna dapat dilihat pola tumbuh ke atas sudah benar, sedangkan pola tumbuh menyamping belum benar ini berarti representasi numerik belum terwakili. Representasi numerik dalam bentuk gambar pola tumbuh ke atas dan ke samping masih kesulitan.

Hasil pekerjaan gambar pola yang dikerjakan siswa perbedaaan level 1 tingkat 
di atasnya agak sulit untuk dibedakan. Berdasarkan hasil penelitian siswa terdistribusi ke dalam 4 tahap yaitu: 5 anak tahap pre-structural, 4 anak tahap emergent, 5 anak tahap partial, dan 7 anak tahap structural.

\section{DAFTAR RUJUKAN}

Aubrey, C., Dahl, S., \& Godfrey, R. 2006. Early Mathematics Development and Later Achievement: Further Evidence. Mathematics Education Research Journal, 18, 27-46.

Butterworth, B., \& Reeve, R. 2008. Verbal Counting and Spatial Strategies in Numerical Tasks : Evidence from Indigenous Australia. Philosophical Psychology, 21, 443-457.

Clements, D.H, \& Sarama, J. 2004 Building Blocks for Early Childhood Mathematics : Early Childhood Research Quarterly 19 (2004) 181189.

Creswell, J. W. 2012. Research Desain Pendekatan Kualitatif, Kuantitatif dan Mixed. Yogyakarta : Pustaka Pelajar:

Doig, B., McCrae, B., \& Rowe, K. 2003. A Good Start to Numeracy: Effective Numeracy Strategies from Research and Practice in Early Childhood. Camberwell, VIC: ACER.

Mulligan, J. T., \&Mitchelmore, M. C. 2009. Awareness of Pattern and Structure in Early Mathematical Development. Mathematics Education Research Journal, 21(2), 33-49.

Mulligan, J.T., English, L.D., Mitchelmore, M. C., Welsby, S. \& Crevensten, N. 2011. An Evaluation of the Pattern and Structure Mathematics Awareness Program in the Early Years of Schooling. In J. Clark, B. Kissane, J.
Mousley, T. Spencer \& S. Thornton (Eds.), Mathematics: Traditions and [New] Practices (Proceedings of the joint conference of the Australian Association of Mathematics Teachers and the Mathematics Education Research Group of Australasia, pp.548556 ). Alice Springs, NT: AAMTMERG

Mulligan. J. T., Mitchelmore, M. C., English, L. D., \& Robertson, G. 2010. Implementing a Pattern and Structure Mathematics Awareness Program (PASMAP) in Kindergarten. In $\mathrm{L}$. Sparrow, B. Kissane, \& C. Hurst (Eds.), Proceedings of the 33rd annual conference of the Mathematics Education Research Group of Australasia Shaping the future of mathematics education (pp. 796-803). Freemantle, Australia: MERGA.

Papic, M., Mulligan, J. T., \& Mitchelmore, M. C. 2011. Assessing the Development of Preschoolers' Mathematical Patterning. Journal for Research in Mathematics Education, Vol. 42, No. 3, 237-268.

Warren, E., \& Cooper, T. J. 2007. Repeating Patterns and Multiplicative Thinking: Analysis of Classroom Interactions with 9 Year Old Students that Support the Transition from Known to the Novel. Journal of Classroom Instruction, 41 (2), 7-11.

Warren, E., \& Cooper, T. J. 2008. Generalising the Pattern Rule for Visual Growth Patterns: Actions that Support 8 Year Olds Thinking. Education Studies in Mathematics. 67(2), 171. 